\title{
Human genome editing and the identity politics of genetic disability
}

\author{
Felicity Boardman ${ }^{1}$ (1)
}

Received: 20 August 2019 / Accepted: 29 August 2019/Published online: 6 September 2019

(C) Springer-Verlag GmbH Germany, part of Springer Nature 2019

As highlighted by Kleiderman and Kellner Stedman's (2019) recent article, the case for the use of genomic technologies, such as CRISPR/cas9 to undertake germline editing of human embryos, has been gaining momentum in recent years. In the UK, for example, a licence was granted to researchers in 2016 to allow CRISPR research using human embryos - although such embryos would not be permitted to develop past 14 days (HFEA 2016).

Monogenetic rare conditions are amongst those most frequently targeted by those developing human genome editing technologies, with recent claims of curative editing techniques being achieved for Duchenne Muscular Dystrophy (Nelson et al. 2019), Fragile X Syndrome (Yrigollen and Davidson 2019) and Cystic Fibrosis (Brothers et al. 2019), despite continued highly restrictive global governance of the practice, ongoing concerns about its future biological impacts and evolving debates regarding its social and ethical implications (Daley et al. 2019; Ormond et al. 2019).

Unlike other forms of reproductive genetic disease prevention, such as pre-conception or prenatal genetic screening, or the use of pre-implantation genetic diagnosis (techniques used to effectively filter out and eradicate embryos and foetuses affected by genetic conditions, or prevent their conception in the first place), germline genome editing techniques differ substantially in their approach to genetic disease prevention. As Cavaliere (2018) has argued, such technologies are targeted towards the correction or removal of disabling genetic traits, rather than the so-called seek and destroy approach of currently used technologies (Rothstein 2001). Through preservation of the life of the embryo (that would otherwise be disabled), and eradication only of the disabling trait, germline genome editing indeed appears to neatly sidestep one of the most critical social and ethical concerns levelled at current methods of genetic disease amelioration: that the disabling

Felicity Boardman

Felicity.Boardman@warwick.ac.uk

1 Warwick Medical School, University of Warwick, Coventry CV4 7AL, UK trait is considered more significant than the life of the embryo or foetus.

Parens and Asch (2000) have been amongst those who have most prominently developed this critique, initially in relation to prenatal testing and selective termination although more recently towards other technologies and practices. Parens and Asch argue that such technological intervention involves otherwise wanted embryos/foetuses being eradicated on the grounds of a single genetic difference: a genetic trait that is assigned such negative value as to render all other characteristics and traits of that (wouldbe) person irrelevant (Parens and Asch 2000). Given the nature of this critique, it does not take a large intellectual leap to arrive at the second most commonly cited disability rights critique of selective reprogenetic practices, known as the 'expressivist objection' (Buchanan 1996). This objection holds that selective reprogenetic practices not only prevent disabled people from coming into existence, but that their very availability — and the associated, and often clandestine, social pressures to use them (Clarke 1991; Markens et al. 2010) - both convey and perpetuate negative views about the particular disabling conditions they are targeted towards, and, by extension, people who currently live with those conditions (Asch and Wasserman 2015). Moreover, these negative appraisals of disability are seen as reverberating throughout wider society, affirming and reinforcing negative appraisals of the lives and worth not only of people who screened/tested for conditions, but of disabled people as a whole (Peterson 2012).

Recent empirical research by myself and other researchers clearly demonstrate the existence, ethical dilemmas and the ambivalence towards genetic technologies that emerge directly from these two concerns about reprogenetic technologies in the accounts of both genetically and non-genetically disabled people (Boardman 2014). My research has revealed, for example, that the majority of people with genetic disabilities feel that it would be a loss to society to have fewer people with their particular condition coming into the world (Boardman and Hale 2018) and the majority (90\%) of family members of 
people with genetic disabilities such as haemophilia, for example, feel uncomfortable with the idea of pregnancy termination for the condition in their family (Boardman et al. 2019).

Despite this burgeoning body of research (e.g. Roadhouse et al. 2018; Barter et al. 2017; Stern et al. 2002; Tanjeja et al. 2004; Maxwell et al. 2011; Potrata et al. 2014; Gollust et al. 2003), however, the voices of the disability community remain largely under-represented in dialogue around the future development of reproductive genomic medicine such as genome editing (Wolbring and Diep 2016), and an ongoing and challenging relationship of mistrust and suspicion has been observed between the disability and genetics communities (Madeo et al. 2011).

The development of human germline genome editing is particularly significant; however, because unlike current practice, it directly challenges the first of the disability rights critiques of selective reproduction outlined above. By retaining - as an alternative to destroying - the (would-be) disabled embryo, and instead removing only the disabling trait, genome editing marks a significant departure in the way in which genetically selective reproduction operates. Whilst, as Kleiderman and Kellner Stedman (2019) outline, for many people with genetic conditions, this possibility suggests clear benefits for the embryo in question, their family and wider society; the assumption that this development is of universal benefit to the disability community may be challenged when expressivist objections and the identity politics of disability and personhood are taken into account.

As Shakespeare (2006) and others outline, research that explores the relationship between disabled people and the concept of cure, or other modes of disability removal (e.g. reprogenetics), is complex and multi-faceted, with disabled people experiencing particular forms of impairment (typically those involving pain, deterioration and shortened-life span) more likely to welcome the notion of disability removal than others (e.g. those with static impairments since birth). For example, recent research on adults with spinal muscular atrophy has highlighted a degree of ambivalence towards the first, and only recently licenced, drug therapy for the condition, nusinersen (Pacione et al. 2019). Some adults with SMA, particularly those with the static form of impairment (type II), regard their condition as an integral part of their personhood and identity and as a mediator of their interactions with the world. This deep cleft in the responses between genetically disabled people with contrasting experiences of their impairment and of disability and also the role of identity politics in their lives has also been mirrored in studies that explore attitudes towards genetic screening (Roadhouse et al. 2018; Boardman et al. 2017; Gollust et al. 2003). A recognition of the emerging literature that explores the role of impairment experiences and identity politics, therefore, is critical to understanding the broad spectrum of responses that are currently being observed amongst genetically disabled people to technologies that ameliorate genetic disability, of which genome editing is but one.

It is not yet possible to explore the new forms of personhood, identity and genetic relatedness that will inevitably emerge amongst individuals subject to embryonic germline genome editing in the future. The argument espoused by many prominent ethicists that life without disability is unequivocally preferable to one with disability would render genome editing a technology of undeniable benefit to the embryo in question (Savulescu et al. 2015; Savulescu and Singer 2019). However, such a focus on the benefit to individual embryos is to overlook the broader societal changes that genome editing will signal, as well as the potential negative impacts on existing persons with genetic conditions (Coller 2019). Indeed, unlike currently used forms of reprogenetic selection, genome editing, by treating germ cells, not only eliminates genetic variation in the treated embryo, but also makes permanent and heritable changes to the germline that will invariably be transferred to offspring, consequently reducing the incidence of the genetic condition in the human gene pool in ways that currently used technologies are not capable of.

People with lived experience of genetic conditions have much to offer our current understanding of the social, personal and ethical implications this technology will have. Expressivist concerns around genome editing, and the potential negative impacts on people with unedited genomes or spontaneous mutations are important considerations as we move towards genomic futures where genome editing is normalised (and non-use socially penalised) along with the inevitable changes to the demographic characteristics of society that will follow (Nuffield Council on Bioethics 2018: 78).

Whilst the technologies and methods of implementation of genomic medicine are likely to transform and shift overtime, the core ethical and social issues that genetic disability eradication and/or minimisation present will invariably remain the same. It is critical, therefore, that the literature exploring the views of people with the most vivid and visceral insights into the lived realities of genetic disability is included and valued in the processes of development and evaluation of new technologies such as genome editing (Petersen 2006). This is not only so that the potential impacts on them can be explored, but also so that informed decisions regarding which conditions are the appropriate targets of genome editing can be made. Indeed, given the inherent potential of germline genome editing, this inclusion is now of paramount importance, when it is considered that such voices and experiences could eventually become a resource of increasing inaccessibility in the future. 


\section{References}

Asch A, Wasserman D (2015) Reproductive testing for disability. In: Arras JD, Fenton E, Kukla R (eds) Routledge companion to bioethics. Routledge, London

Barter B, Hastings RP, Williams R, Huws JV (2017) Perceptions and discourses relating to genetic testing: interviews with people with Down syndrome. J Appl Res Intellect Disabil 30(2):395-406

Boardman F (2014) The expressivist objection to prenatal testing: the experiences of families living with genetic disease. Soc Sci Med 107:18-25

Boardman F, Hale R (2018) How do genetically disabled adults view selective reproduction? Impairment, identity and genetic screening. Mol Genet Genomic Med 6(6):941-956

Boardman F, Young P, Griffiths F (2017) Impairment experiences, identity and attitudes towards genetic screening: the views of people with spinal muscular atrophy. J Genet Couns 27(1):69-84

Boardman F, Hale R, Gohel R, Young P (2019) Preventing lives affected by haemophilia: a mixed methods study of the views of haemophiliac adults and their families towards genetic screening. Mol Genet Genomic Med 7(5):e618. https://doi.org/10.1002/ mgg3.618

Brothers KB, Devereaux M, Sade RM (2019) Bespoke babies: genome editing in cystic fibrosis embryos. Ann Thorac Surg. https://doi.org/ 10.1016/j.athoracsur.2019.04.030

Buchanan A (1996) Choosing who will be disabled: genetic intervention and the morality of inclusion. Soc Philos Policy 13:18-46

Cavaliere G (2018) Genome editing and assisted reproduction: curing embryos, society or prospective parents? Med Health Care Phil $21: 215-225$

Clarke A (1991) Is non-directive genetic counselling possible? Lancet 338(19):998-1001

Coller BS (2019) Ethics of human genome editing. Annu Rev Med 70: 289-305

Daley GQ, Lovell-Badge R, Steffann J (2019) After the storm - a responsible path for genome editing. N Engl J Med 380:897-899

Gollust SE, Thompson RE, Gooding HC, Biesecker BB (2003) Living with achondroplasia: attitudes towards population screening ad correlation with quality of life. Prenat Diagn 23:1003-1008

Human Embryology and Fertilisation Authority (2016) License Committee Minutes(14 ${ }^{\text {th }}$ January), https://www.hfea.gov.uk/media/ 2444/licence-committee-minutes-14-january-2016.pdf. Accessed $11 / 08 / 19$

Kleiderman E, Kellner Stedman IN (2019) Human germline genome editing is illegal in Canada, but could it be desirable for some members of the rare disease community? J Community Genet. https://doi. org/10.1007/s12687-019-00430-x

Madeo AC, Biesecker BB, Brasington C, Erby LH, Peters KF (2011) The relationship between the genetic counseling profession and the disability community: a commentary. Am J Med Genet A 155:17771785

Markens S, Browner C, Preloran HM (2010) Interrogating the dynamics between power, knowledge and pregnant bodies in amniocentesis decision making. Sociol Health Ill 32(1):37-56

Maxwell SJ, Kyne G, Molster C, Barker NM, Ormsby J, O'Leary P (2011) Perceptions of population cystic fibrosis prenatal and preconception carrier screening among individuals with cystic fibrosis and their family members. Genet Test Mol Bioma 15(3):159-164

Nelson CE, Wu Y, Gemberling MP, Oliver ML, Waller MA, Bohning JD, Robinson-Hamm JN, Bulaklak K, Catellanos Rivera RM, Collier JH, Asokan A, Gersbach CA (2019) Long-term evaluation of AAV-CRISPR genome editing for Duchenne muscular dystrophy. Nat Med 25:427-432

Nuffield Council on Bioethics (2018) Genome editing and human reproduction: social and ethical issues. Nuffield Council on Bioethics, London

Ormond K, Bombard Y, Bonham V, Hoffman-Andrews L, Howard H, Isasi R, Musunuru K, Riggan K, Michie M, Allyse M (2019) The clinical application of gene editing: ethical and social issues. Pers Med 16(4):337-350

Pacione M, Siskind C, Day J, Tabor H (2019) Perspectives on Spinraza (Nusinersen) treatment study: views of individuals and parents of children diagnosed with spinal muscular atrophy. J Neuromusc Dis 6:119-131

Parens E, Asch A (2000) The disability rights critique of prenatal testing: reflections and recommendations. In: Parens E, Asch A (eds) Prenatal testing and disability rights. Georgetown University Press, Washington DC

Petersen A (2006) The best experts: the narratives of those who have a genetic condition. Soc Sci Med 63:32-42

Peterson M (2012) Disability advocacy and reproductive choice: engaging with the expressivist objection. J Genet Couns 21:13-16

Potrata B, McKibbin M, Lim JNW, Hewison J (2014) "To perpetuate blindness!": attitudes of UK patients with inherited retinal disease towards genetic testing. J Genet Couns 5:215-222

Roadhouse C, Shuman C, Anstey K, Sappleton K, Chitayat D, Ignagni E (2018) Disability experiences and perspectives regarding reproductive decisions, parenting and the utility of genetic services: a qualitative study. J Genet Couns 27:1360-1373

Rothstein J (2001) Impairments: always linked to meaningful disability? Phys Ther 81(3):886-887

Savulescu J, Singer P (2019) An ethical pathway for gene editing. Bioethics 32(2):221-222

Savulescu J, Pugh J, Douglas Tm Gyngell C (2015) The moral imperative to continue gene editing research on human embryos. Protein Cell 6(7):476-479

Shakespeare T (2006) Disability rights and wrongs. Routledge, London

Stern SJ, Arnos KS, Murrelle L, Oelrich Welch K, Nance WE, Pandya A (2002) Attitudes of deaf and hard of hearing subjects towards genetic testing and prenatal diagnosis of hearing loss. J Med Genet 39(6): $449-453$

Tanjeja PR, Pandya A, Foley DL, Nicely LV, Arnos KS (2004) Attitudes of deaf individuals towards genetic testing. Am J Med Genet A 130A(1):17-21

Wolbring G, Diep L (2016) The discussions around precision genetic engineering: role of and impact on disabled people. Laws 5(3):3760

Yrigollen CM, Davidson BL (2019) CRISPR to the rescue: advances in gene editing for the FMR1 gene. Brain Sci 9(1):17

Publisher's note Springer Nature remains neutral with regard to jurisdictional claims in published maps and institutional affiliations. 